\title{
Glycosyltransferases in Human Blood
}

\author{
I. GALACTOSYLTRANSFERASE IN HUMAN SERUM AND \\ ERYTHROCYTE MEMBRANES
}

\author{
Young S. Kim, Jose Perdomo, and James S. Whitehead \\ From the Gastrointestinal Research Laboratory, Veterans Administration \\ Hospital, San Francisco, California 94121, and Department of Medicine, \\ University of California School of Medicine, San Francisco, California 94122
}

\begin{abstract}
A в S T R A C T Human serum and hemoglobin-free erythrocyte membranes were found to contain a galactosyltransferase which catalyzes the transfer of galactose from UDP-galactose to specific large and small molecular weight acceptors. The requirements for enzyme activity were found to be similar for the enzymes from both sources. However, the membrane-bound enzyme depended on a detergent for maximal activity. $\mathrm{Mn}^{++}$was an absolute requirement for transfer and uridine nucleoside phosphates were inhibitors. The most effective acceptor for galactose was a glycoprotein containing $\mathrm{N}$-acetylglucosamine residues in the terminal position of its oligosaccharide side chains. $\mathrm{N}$-acetylglucosamine was also an acceptor. While the presence of $\alpha$-lactalbumin in the incubation medium resulted in a significant decrease in the transfer of galactose to $\mathrm{N}$-acetylglucosamine, glucose, which was not an acceptor for galactose in the absence of $\alpha$-lactalbumin, became an excellent acceptor. The serum enzyme catalyzed the transfer of 54 nmoles of galactose per milliliter of serum per hour and its apparent $K_{m}$ for UDP-galactose was $7.5 \times 10^{-6} \mathrm{M}$. The membrane enzyme had a similar apparent $K_{m}$. Using a quantitative assay system the enzyme was found to be present in all individuals studied, regardless of their blood type, secretor status, or sex.
\end{abstract}

\section{INTRODUCTION}

Glycoproteins and glycolipids have been shown to be present in the plasma membranes of many mammalian cells including erythrocytes (1-9). Although numerous biological roles have been ascribed to these substances such as $A B O$ and $M N$ blood group antigenicity (3-8), ability to inhibt influenza virus hemagglutination reac-

Received for publication 18 January 1972 and in revised form 6 March 1972. tions (9), tumor antigenicity (10-11), ion and macromolecular transport (12), and control of cellular adhesion $(13,14)$, little is known about their chemistry and biosynthesis. In the synthesis of glycoproteins and glycolipids glycosylation is achieved by a family of related enzymes, i.e., a multiglycosyltransferase system (15). In general, they are membrane-bound in the tissues and each such enzyme transfers a specific sugar from a nucleotide-sugar substrate to an acceptor of discrete structure.

We have recently reported the presence of two glycosyltransferases, an $N$-acetylgalactosaminyltransferase (16) and a sialyltransferase (17) in erythrocyte membranes and in the serum of man. The $N$-acetylgalactosaminyltransferase was detected on the erythrocyte membranes and in the sera only of individuals of blood type $A$ and $A B$ but not in those of types B or O. In contrast, the sialyltransferase was present in all individuals studied regardless of their blood groups. Unfortunately, due to the lack of available substrates with low specific radioactivity, a comparative study of the kinetics of these enzymes from the two sources could not be performed.

Galactosyltransferases, which catalyze the transfer of galactose from UDP-galactose ${ }^{1}$ to low and high molecular weight acceptors, have been described in various tissues and secretions (18-25). The present investigations were carried out in order to develop a quantitative assay system for the galactosyltransferase in blood. The catalytic properties and acceptor specificity of this glycosyl-

\footnotetext{
${ }^{1}$ Abbreviations used in this paper: AMP, ADP, ATP, mono, di, and triphosphoadenosine; Fuc, fucose; Gal, galactose; GalN, galactosamine; GalNAc, $N$-acetylgalactosamine ; Glc, glucose; GlcN, glucosamine; GlcNAc, $N$-acetylglucosamine; GMP, GDP, GTP, mono, di, and triphosphoguanosine; Man, mannose; OSM, ovine submaxillary mucin; UDP-Gal and UDP-galactose, uridine diphosphate galactose ; UPM, UDP, UTP, mono, di, and triphosphouridine.
} 
transferase were examined in human serum and in erythrocyte membranes. The relationships of this enzyme to the $\mathrm{ABO}$ and $\mathrm{MN}$ blood group activities and to the secretor status of the individual were also studied.

\section{METHODS}

Preparation of samples. Hemoglobin-free erythrocyte membranes were prepared from fresh blood obtained from volunteers according to a previously published modification (17) of the method of Dodge et al. (26). Serum was obtained from fresh plasma by allowing it to clot at $4^{\circ} \mathrm{C}$ as described (17).

Preparation of glycosyltransferase acceptors. On the basis of previous work $(27,28)$, which allowed definition of their molecular structure, and in particular of the end groups involved in glycosyltransferase reactions, two glycoprotein acceptors were chosen: firstly fetuin, whose carbohydrate moiety ends in the sequence GlcNAc-Gal-sialic acid and secondly, ovine submaxillary mucin (OSM), possessing the sequence of GalNAc-sialic acid. Fetuin was isolated from fetal calf serum by the method of Spiro (29). The fetuin acceptor was prepared by removing the sialic acid and the galactose moieties of fetuin by mild acid hydrolysis, followed by the Smith degradation procedure as described by Spiro (27). The ovine submaxillary mucin acceptor was prepared by treatment of the mucin with neuraminidase (Vibrio cholerae), employing essentially the method used by Payza, Rizvi, and Pigman (30) for the preparation of sialic acid free porcine submaxillary mucin.

Enzyme assay. Unless stated otherwise, incubations of the reaction mixtures were carried out at $30^{\circ} \mathrm{C}$ for $2 \mathrm{hr}$ in a shaking water bath and were terminated by the addition of $5 \mathrm{ml}$ cold $1 \%$ phosphotungstic acid in $0.5 \mathrm{~N} \mathrm{HCl}$. Bovine serum albumin $(0.8 \mathrm{mg})$ was added as a carrier protein and the precipitate was washed three times with cold $1 \%$ phosphotungstic acid, dissolved in $0.5 \mathrm{ml}$ of NCS solubilizer (Amersham/Searle Corp., Arlington Heights, Ill.) at $50^{\circ} \mathrm{C}$ and counted in a Packard Tri-Carb liquid scintillation spectrometer (Packard Instrument Co., Inc., Downers Grove, I11.) with toluene-phosphor. When monosaccharides were used as the acceptor, the reaction was stopped by heating the tubes at $100^{\circ} \mathrm{C}$ for $30 \mathrm{sec}$. Tubes were then centrifuged and the supernatant fluid was passed through a column $(9 \times 20$ $\mathrm{mm}$ ) packed with a mixed bed resin (Dowex-1 X 8 formate form and Dowex-50W X 8 hydrogen form). The precipitate was washed twice with distilled water and washings were also passed through the column. The combined effluent and washings were dried at $100^{\circ} \mathrm{C}$ in a counting vial and counted as described above. Values were corrected for quenching or self-absorption by the use of an external standard. Control incubations were performed in all instances in the absence of either exogenous acceptor or enzyme and in calculating enzyme-mediated incorporation into the acceptors the sum of the radioactivity incorporated into both controls was subtracted from the total radioactivity.

The incubation mixture for the assay of galactosyltransferase contained the following: $122,000 \mathrm{dpm}$ of UDP-Dgalactose- ${ }^{14} \mathrm{C}(6 \mathrm{mCi} / \mathrm{mmole})$ prepared by mixing UDP-Dgalactose $-{ }^{14} \mathrm{C}(298 \mathrm{mCi} / \mathrm{mmole}$, New England Nuclear Corp., Boston, Mass.) with unlabeled UDP-D-galactose (Sigma Chemical Co., St. Louis, Mo.), enzyme (20 $\mu$ l of serum or $0.5 \mathrm{mg}$ protein of erythrocyte membrane), $1.5 \mathrm{mg}$ of the fetuin acceptor, $13 \mu$ moles of $\mathrm{MnCl}_{2}, 0.33 \mathrm{mg}$ of Triton X-100 (only in erythrocyte membrane assays), and $66 \mu$ moles of cacodylateacetate buffer, $\mathrm{pH} 7.5$, in a final volume of 0.33 $\mathrm{ml}$. When low molecular weight acceptors were employed, $2 \mu$ moles of acceptor were added to a similar incubation mixture except that the serum was dialyzed before use as a source of the enzyme to remove potential small molecular weight acceptors. The protein contents of the samples were determined by the method of Lowry, Rosebrough, Farr, and Randall (31).

$\alpha$-Lactalbumin preparation. Bovine $\alpha$-lactalbumin was obtained from Schwarz-Mann Laboratories, Orangeburg, N. Y. The material was dissolved in water $(15 \mathrm{mg} / \mathrm{ml})$. To eliminate contaminating galactosyltransferase activity, the sample was heated for $20 \mathrm{~min}$ at $80^{\circ} \mathrm{C}$.

Identification of the labeled reaction product. For the identification of the labeled sugar incorporated into glycoprotein acceptors, the reaction product was precipitated and hydrolyzed in $3 \mathrm{~N} \mathrm{HCl}$ under nitrogen at $100^{\circ} \mathrm{C}$ for $4 \mathrm{hr}$. The hydrolysate was filtered through glass wool and the $\mathrm{HCl}$ evaporated at $50^{\circ} \mathrm{C}$. The residue was dissolved in water and chromatographed on Whatman $3 \mathrm{MM}$ paper in ethyl acetate-pyridine-water $(12: 5: 4 \mathrm{v}: \mathrm{v})$ for $15 \mathrm{hr}$ at $25^{\circ} \mathrm{C}$. A $2 \mathrm{~cm}$ wide strip was cut and the strip was divided into $2.0-\mathrm{cm}$ long sections. Each section was cut into small squares and counted in a Packard Tri-Carb liquid scintillation spectrometer with toluene-phosphor. The standard monosaccharides used for chromatography were D-galactosamine, Dglucosamine, D-galactose, D-glucose, D-mannose, and L-fucose, obtained from Mann Research Labs, Inc., New York.

TABLE I

Requirements of Human Serum and Erythrocyte Membrane Galactosyltransferases

\begin{tabular}{|c|c|c|}
\hline Incubation mixture & $\begin{array}{l}\text { Enzyme } \\
\text { activity }\end{array}$ & $\begin{array}{c}\text { Per cent } \\
\text { activity }\end{array}$ \\
\hline & $d p m / 2 h r$ & $\%$ \\
\hline \multicolumn{3}{|l|}{ Serum enzyme } \\
\hline Complete assay mixture* & 19,250 & 100 \\
\hline Minus enzyme & 11 & 0.1 \\
\hline Minus acceptor & 16 & 0.1 \\
\hline Minus $\mathrm{MnCl}_{2}$ & 35 & 0.2 \\
\hline Minus $\mathrm{MnCl}_{2}$ plus $25 \mathrm{~mm}$ EDTA & 33 & 0.2 \\
\hline Minus $\mathrm{MnCl}_{2}$ plus $21 \mathrm{~mm} \mathrm{MgCl}_{2}$ & 20 & 0.2 \\
\hline Minus $\mathrm{MnCl}_{2}$ plus $21 \mathrm{~mm} \mathrm{CaCl}_{2}$ & 19 & 0.1 \\
\hline Plus $0.33 \mathrm{mg}$ Triton $\mathrm{X}-100$ & 19,996 & 103.8 \\
\hline \multicolumn{3}{|l|}{ Erythrocyte membrane enzyme } \\
\hline Complete assay mixture* & 2,400 & 100 \\
\hline Minus enzyme & 11 & 0.5 \\
\hline Minus acceptor & 11 & 0.5 \\
\hline Minus $\mathrm{MnCl}_{2}$ & 12 & 0.5 \\
\hline Minus $\mathrm{MnCl}_{2}$ plus $25 \mathrm{~mm}$ EDTA & 15 & 0.6 \\
\hline Minus $\mathrm{MnCl}_{2}$ plus $21 \mathrm{~mm} \mathrm{MgCl}_{2}$ & 20 & 0.8 \\
\hline Minus $\mathrm{MnCl}_{2}$ plus $21 \mathrm{~mm} \mathrm{CaCl} 2$ & 18 & 0.7 \\
\hline Minus $0.33 \mathrm{mg}$ Triton $\mathrm{X}-100$ & 195 & 8.1 \\
\hline
\end{tabular}

* The complete incubation mixture contained the following: 122,000 idpm of UDP-D-galactose- ${ }^{14} \mathrm{C}(6 \mathrm{mCi} / \mathrm{mmole}), 20 \mu \mathrm{l}$ of serum or $0.5 \mathrm{mg}$ protein erythrocyte membrane, $1.5 \mathrm{mg}$ of fetuin acceptor, $13 \mu$ moles of $\mathrm{MnCl}_{2}, 0.33 \mathrm{mg}$ of Triton $\mathrm{X}-100$ (for membrane assay only) and $66 \mu$ mole sof cacodylateacerate buffer $\mathrm{pH} 7.5$ in a final volume of $0.33 \mathrm{ml}$. 


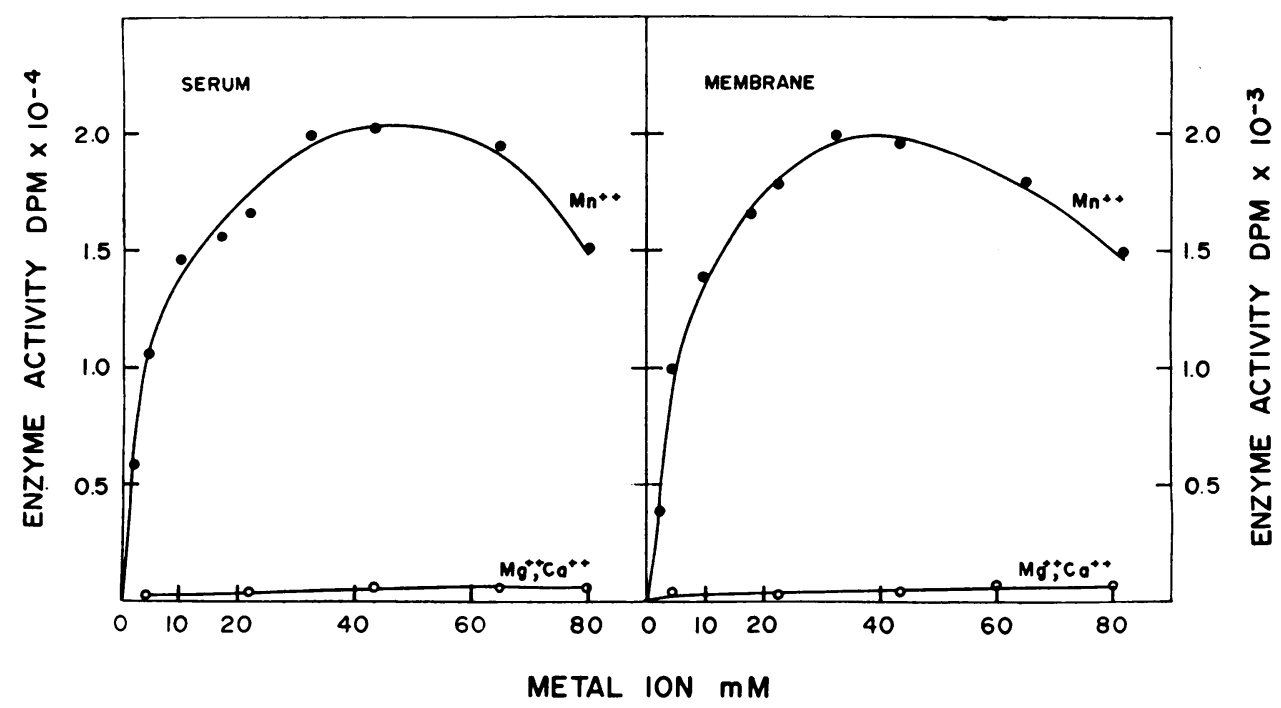

FIGURE 1 The effect of $\mathrm{Mn}^{++}$concentration on the galactosyltransferase activity of serum and erythrocyte membrane. Incubations were carried out as described in Methods for the standard assay procedure.

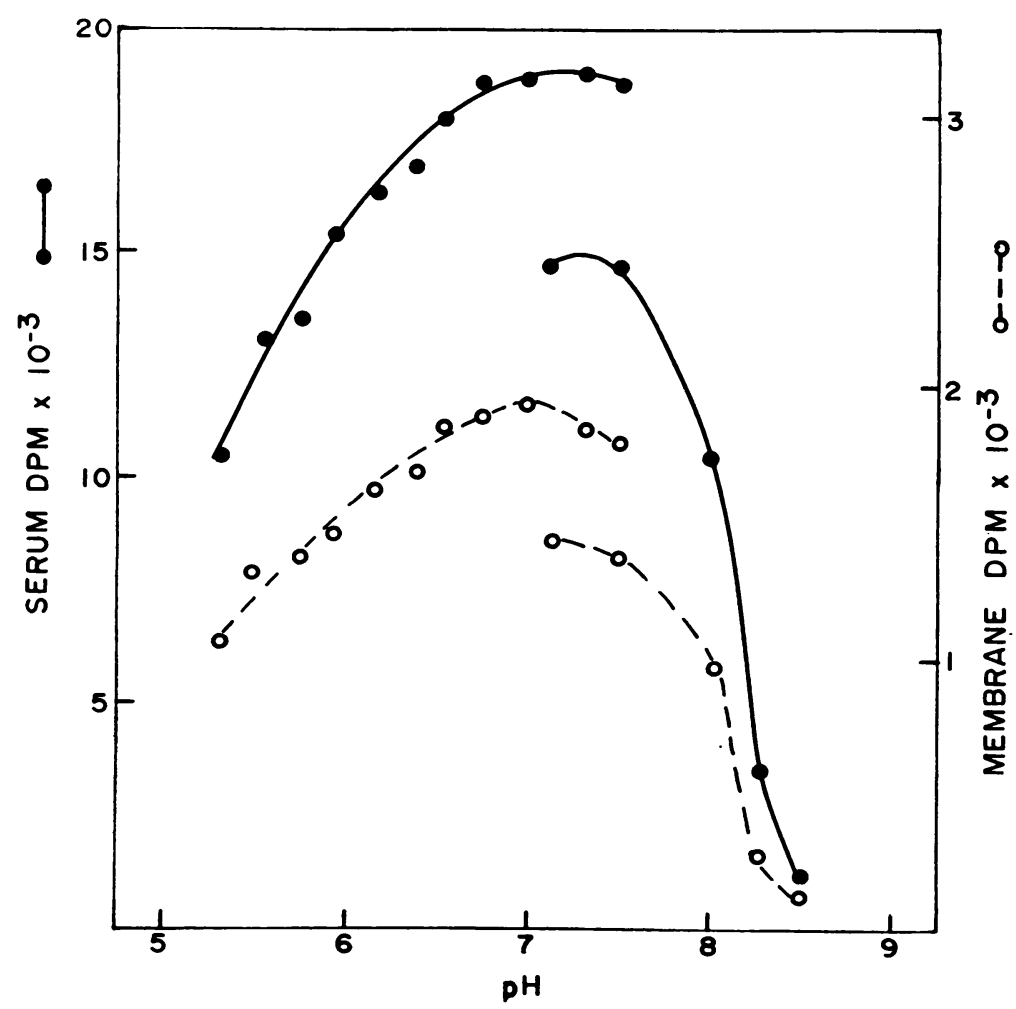

FIGURE 2 The effect of $\mathrm{pH}$ on the transfer of galactose by serum and erythrocyte membranes from UDP-Gal to fetuin acceptor. $\longrightarrow$, serum; $\bigcirc-\bigcirc$, erythrocyte membranes; from $\mathrm{pH} 5.3$ to 7.5 cacodylate-acetate buffer; from 7.2 to 8.5 Tris-acetate buffer. Incubation conditions are those described in Methods. 


\section{RESULTS}

Serum and erythrocyte membrane galactosyltransferase. The conditions for optimal enzyme activity are shown in Table I. Virtually no incorporation of galactose occurred when the acceptor was deleted. Manganous ion was an absolute requirement for the incorporation of galactose by the enzyme from serum or erythrocyte membrane. Neither $\mathrm{Ca}^{++}$nor $\mathrm{Mg}^{++}$was able to substitute for $\mathrm{Mn}^{++}$. The optimal $\mathrm{Mn}^{++}$concentration was $43 \mathrm{~mm}$ for either enzyme (Fig. 1). Of 13 detergents tested, Triton $\mathrm{X}-100$ proved most effective but was only required for the erythrocyte membrane enzyme. Sodium deoxycholate gave results comparable to those obtained with Triton X-100. The enzyme from both sources had a $\mathrm{pH}$ optimum of 7.0 (Fig. 2) and maximal incorporation occurred at $30^{\circ} \mathrm{C}$ (Fig. 3). The incorporation of galactose into the acceptor under the standard incubation conditions was linear with regard to enzyme concentration up to $75 \mu 1$ of serum and $0.5 \mathrm{mg}$ protein of erythrocyte membrane (Fig. 4) and the reaction was proportional to the length of incubation for up to $6 \mathrm{hr}$ (Fig. 5). The serum and erythrocyte membrane enzymes retained full activity on storage for $5 \mathrm{wk}$ at $-20^{\circ} \mathrm{C}$. The enzyme from both sources was completely inhibited by $1.25 \mathrm{~mm} p$-chloromercuribenzoate. The apparent $K m$ values of the serum and erythrocyte membrane enzymes for UDP-galactose were $7.5 \times 10^{-8} \mathrm{M}$ and $5.0 \times 10^{-8} \mathrm{M}$, respectively (Fig. 6). Fig. 7 shows the effect of varying the concentration of the fetuin acceptor on galactose incorporation with the serum and erythrocyte membrane enzymes. Acceptor saturation under the standard assay conditions was achieved by the addition of $1.0 \mathrm{mg}$ of the fetuin acceptor to the serum assay and $0.5 \mathrm{mg}$ to the erythrocyte membrane enzyme incubation mixture.

Effect of nucleoside phosphates on galactosyltransferase activity. Table II shows the effects of various

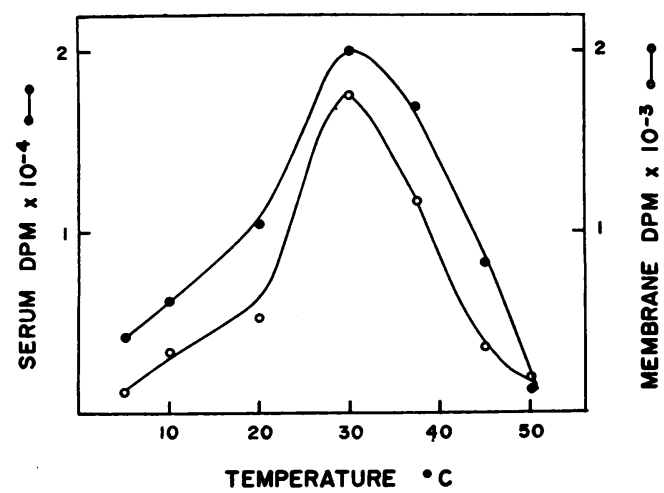

Figure 3 The effect of temperature on galactosyltransferase activity of serum and erythrocyte membranes. Incubation conditions are those described in Methods.

nucleoside phosphates on the incorporation of galactose into the fetuin acceptor by the serum enzyme. Additions of adenosine or guanosine phosphates had little influence on the transfer of galactose at concentrations of either $1 \mathrm{~mm}$ or $10 \mathrm{~mm}$. In contrast, the incorporation of galactose was markedly inhibited by UDP, UTP, and UMP even at concentrations of $0.1 \mathrm{mM}$; UDP showed the most significant inhibition.

Characterization of incorporated sugar. The radioactive sugar incorporated into fetuin by the serum and erythrocyte membrane galactosyltransferase with UDPgalactose as the substrate was examined. Galactose was the only radioactive compound detected as shown in Fig. 8, indicating that no conversion to other sugar nucleotides occurred during the reaction.

The effect of $\alpha$-lactalbumin on the galactosyltransferase acceptor specificity. Table III shows the acceptor specificity of the galactosyltransferase from serum and erythrocyte membranes. In the absence of $\alpha$ lactalbumin, the enzyme from either source did not

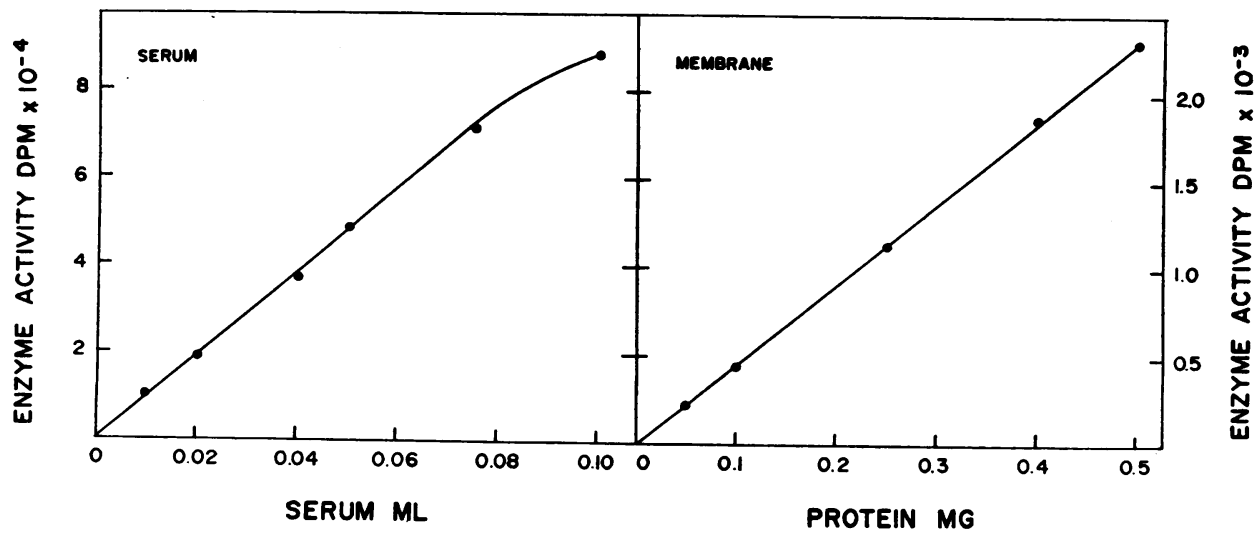

FIGURE 4 Effect of varying enzyme concentration on incorporation of galactose into fetuin acceptor. Incubation conditions are those described in Methods. 


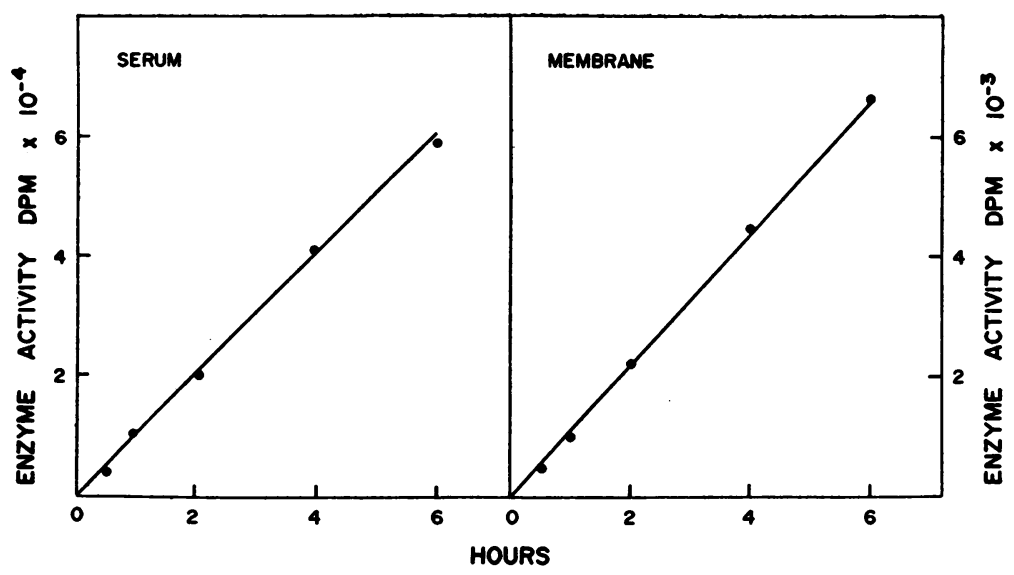

FIGURE 5 Effect of incubation time on the degree of incorporation of galactose into fetuin acceptor. Conditions for assay are those described in Methods.

utilize glucose as an acceptor. When $\alpha$-lactalbumin was added, the transfer of galactose to glucose to form lactose occurred. When $\alpha$-lactalbumin was absent from the incubation mixture, $N$-acetylglucosamine and the fetuin acceptor with terminal $\mathrm{N}$-acetylglucosamine residues were the most effective acceptors for the enzyme from either source. By contrast the presence of $\alpha$-lactalbumin markedly diminished the transfer of galactose to $N$ acetylglucosamine by either enzyme. However, $\alpha$-lactalbumin had little effect on the transfer of this sugar to the fetuin acceptor.

The transfer of galactose to $N$-acetylgalactosamine was detected only when the serum enzyme was used. When an OSM with terminal $N$-acetylgalactosamine residues was the acceptor, moderate incorporation of galactose was catalyzed by the serum enzyme but a low level of transfer occurred with the erythrocyte mem- brane preparation. Using these acceptors no effect on glycosylation was observed when $\alpha$-lactalbumin was included in the reaction mixture.

The level of the galactosyltransferase in serum and on erythrocyte membranes was examined in individuals differing in blood group and secretor status (Table IV). These results indicate no significant difference in the galactosyltransferase level among the groups studied.

\section{DISCUSSION}

The enzyme studied herein catalyzes the transfer of galactose from UDP-galactose to specific large and small molecular weight acceptors (Fig. 9). A galactosyltransferase with similar acceptor specificities to the enzyme examined here is required for the biosynthesis of serum glycoproteins (32) and for intermediate stages in the biosynthesis of $\mathrm{ABO}$ blood group substances
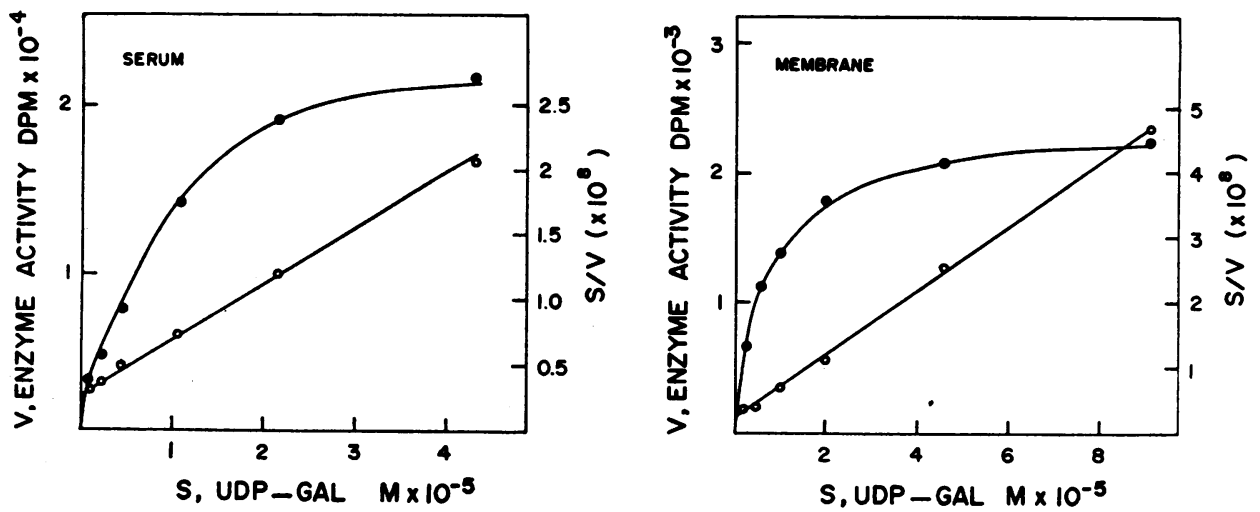

FIGURE 6 Effect of UDP-galactose concentration on the incorporation of galactose into fetuin acceptor. Incubation conditions are those described in Methods. The apparent $K_{m}$ values for UDP-galactose were $7.5 \times 10^{-6} \mathrm{M}$ and $5.0 \times 10^{-6} \mathrm{M}$ for the serum and erythrocyte membrane enzymes, respectively. $\mathrm{V}, \longrightarrow$ and $\mathrm{S} / \mathrm{V}, \mathrm{O}-\mathrm{O}$. 

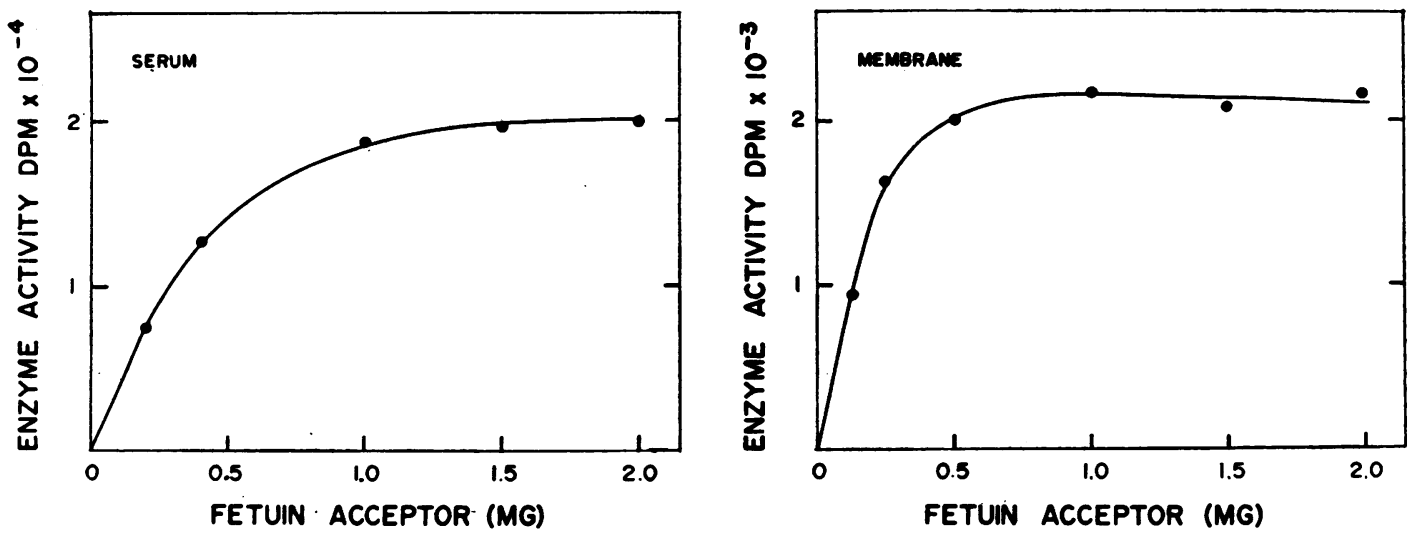

FIGURE 7 Effect of acceptor concentration on incorporation of galactose. Incubation conditions used were those described in the Methods.

TABLE II

Effect of Nucleoside Phosphates on Galactosyltransferase Activity

\begin{tabular}{|c|c|c|c|c|}
\hline \multirow{2}{*}{$\begin{array}{l}\text { Nucleoside } \\
\text { phosphate } \\
\text { added }\end{array}$} & \multicolumn{2}{|c|}{ Serum } & \multicolumn{2}{|c|}{ Erythrocyte membrane } \\
\hline & $\begin{array}{l}\text { Enzyme } \\
\text { activity }\end{array}$ & $\begin{array}{l}\text { Per cent } \\
\text { change }\end{array}$ & $\begin{array}{l}\text { Enzyme } \\
\text { activity }\end{array}$ & $\begin{array}{l}\text { Per cent } \\
\text { change }\end{array}$ \\
\hline None added & $\begin{array}{c}d p m / 2 \mathrm{hr} \\
28,750\end{array}$ & $\%$ & $\begin{array}{c}d p m / 2 h r \\
2,096\end{array}$ & $\%$ \\
\hline $\begin{array}{r}\text { UTP } 0.1 \mathrm{mM} \\
1.0 \mathrm{mM} \\
10.0 \mathrm{mM}\end{array}$ & $\begin{array}{r}23,715 \\
11,460 \\
1,880\end{array}$ & $\begin{array}{l}-17.5 \\
-60.1 \\
-93.5\end{array}$ & $\begin{array}{r}1,380 \\
833 \\
128\end{array}$ & $\begin{array}{l}-34.1 \\
-60.3 \\
-93.9\end{array}$ \\
\hline $\begin{array}{r}\text { UDP } 0.1 \mathrm{~mm} \\
1.0 \mathrm{~mm} \\
10.0 \mathrm{~mm}\end{array}$ & $\begin{array}{r}12,930 \\
2,370 \\
250\end{array}$ & $\begin{array}{l}-55.1 \\
-91.8 \\
-99.1\end{array}$ & $\begin{array}{r}1,144 \\
260 \\
33\end{array}$ & $\begin{array}{l}-45.4 \\
-87.6 \\
-98.4\end{array}$ \\
\hline $\begin{array}{r}\text { UMP } 0.1 \mathrm{mM} \\
1.0 \mathrm{mM} \\
10.0 \mathrm{mM}\end{array}$ & $\begin{array}{r}23,700 \\
8,380 \\
1,240\end{array}$ & $\begin{array}{l}-17.6 \\
-70.9 \\
-97.2\end{array}$ & $\begin{array}{r}1,885 \\
891 \\
139\end{array}$ & $\begin{array}{l}-10.1 \\
-57.5 \\
-93.4\end{array}$ \\
\hline $\begin{array}{r}\text { ATP } 1.0 \mathrm{mM} \\
10.0 \mathrm{mM}\end{array}$ & $\begin{array}{l}25,580 \\
23,020\end{array}$ & $\begin{array}{l}-11.1 \\
-20.0\end{array}$ & $\begin{array}{l}2,048 \\
1,557\end{array}$ & $\begin{array}{r}-2.3 \\
-25.7\end{array}$ \\
\hline $\begin{array}{r}\text { ADP } 1.0 \mathrm{~mm} \\
10.0 \mathrm{mM}\end{array}$ & $\begin{array}{l}27,240 \\
23,200\end{array}$ & $\begin{array}{r}-5.3 \\
-19.3\end{array}$ & $\begin{array}{l}1,968 \\
1,705\end{array}$ & $\begin{array}{r}-6.1 \\
-18.7\end{array}$ \\
\hline $\begin{array}{r}\text { AMP } 1.0 \mathrm{mM} \\
10.0 \mathrm{mM}\end{array}$ & $\begin{array}{l}27,320 \\
26,960\end{array}$ & $\begin{array}{l}-5.0 \\
-6.2\end{array}$ & $\begin{array}{l}1,961 \\
1,810\end{array}$ & $\begin{array}{r}-6.4 \\
-13.7\end{array}$ \\
\hline $\begin{array}{r}\text { GTP } 1.0 \mathrm{mM} \\
10.0 \mathrm{mM}\end{array}$ & $\begin{array}{l}28,780 \\
22,400\end{array}$ & $\begin{array}{r}+0.1 \\
-22.1\end{array}$ & $\begin{array}{l}\text { ND } \\
\text { ND }\end{array}$ & \\
\hline $\begin{array}{r}\text { GDP } 1.0 \mathrm{mM} \\
10.0 \mathrm{~mm}\end{array}$ & $\begin{array}{l}27,530 \\
24,640\end{array}$ & $\begin{array}{r}-4.2 \\
-14.3\end{array}$ & $\begin{array}{l}\text { ND } \\
\text { ND }\end{array}$ & \\
\hline $\begin{array}{r}\text { GMP } 1.0 \mathrm{mM} \\
10.0 \mathrm{mM}\end{array}$ & $\begin{array}{l}27,780 \\
27,530\end{array}$ & $\begin{array}{l}-3.4 \\
-4.2\end{array}$ & $\begin{array}{l}\text { ND } \\
\text { ND }\end{array}$ & \\
\hline
\end{tabular}

The assays were performed as described in Methods except that a $25 \mu$ l portion of serum was used. The concentration of nucleoside phosphates indicated are the final concentrations in the incubation mixture. Per cent change represents the difference in activities between the incorporation in the presence and absence of nucleoside phosphate. ND, not determined.
(33) as well as for the formation of lactose in lactating mammary glands (34).

In the present studies such an enzyme has been found to be located in the serum and on erythrocyte membranes of all individuals studied, regardless of their blood type or secretor status. The galactosyltransferase from both sources had very similar catalytic properties. Both had an absolute requirement for $\mathrm{Mn}^{++}$ and had similar temperature, metal ion concentration, and $\mathrm{pH}$ optima and had the same acceptor specificities. They differed, however, in their requirement for a detergent. While a detergent was required for the expression of the erythrocyte membrane enzyme, its

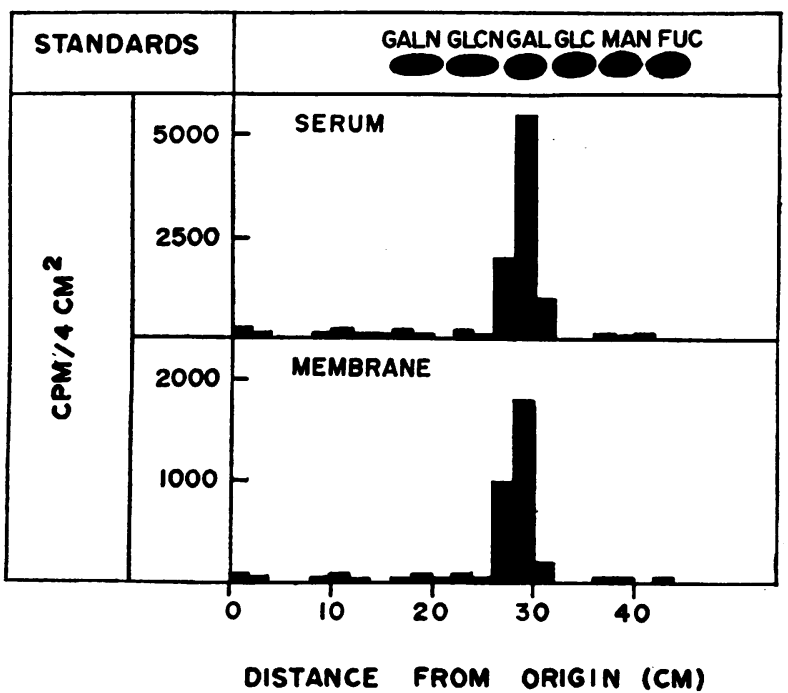

FIGURE 8 Chromatographic identification of incorporated sugar. Fetuin was used as the acceptor. The reaction mixture was scaled up three-fold for the erythrocyte membrane incubation. The conditions used were the same as in the standard assay procedure. Hydrolysis and paper chromatography were performed as described in the Methods. 
TABLE III

Galactosyltransferase Activity Using Various Acceptors in the Presence and Absence of $\alpha$-Lactalbumin

\begin{tabular}{|c|c|c|c|c|}
\hline \multirow[b]{3}{*}{ Acceptor } & \multicolumn{2}{|c|}{ Serum enzyme } & \multicolumn{2}{|c|}{$\begin{array}{l}\text { Membrane } \\
\text { enzyme }\end{array}$} \\
\hline & \multicolumn{2}{|c|}{$\alpha$-lactalbumin } & \multicolumn{2}{|c|}{$\alpha$-lactalbumin } \\
\hline & - & + & - & + \\
\hline & \multicolumn{4}{|c|}{$d p m / 2 \mathrm{hr}$} \\
\hline D-glucose & $\mathbf{0}$ & 14,760 & $\mathbf{0}$ & 3,920 \\
\hline$N$-acetyl-D-glucosamine & 18,420 & 1,440 & 3,210 & 680 \\
\hline$N$-acetyl-D-galactosamine & 780 & 560 & 0 & $\mathbf{0}$ \\
\hline Fetuin acceptor & 27,730 & 21,850 & 1,830 & 1,290 \\
\hline OSM acceptor & 1,940 & 1,620 & 110 & 90 \\
\hline
\end{tabular}

Incubation was carried out as described in Methods. $750 \mu \mathrm{g}$ of bovine $\alpha$-lactalbumin was added. $25 \mu \mathrm{l}$ of serum was used as a source of the enzyme.

presence in the serum enzyme incubation mixture had little effect. This dependence of the membrane enzyme on the presence of a detergent indicates that the observed membrane enzyme activity is not due to contamination of the erythrocyte membrane preparation by serum. At the present time the mechanism by which detergents facilitate the assay of the membrane-bound enzyme is unknown.

The inhibition of activity observed with UDP is not surprising (35). Since UDP is likely to be a product of the reaction, it may compete with the substrate, UDP-galactose, for a binding site on the enzyme. UMP and UTP were also inhibitory but to a lesser degree. Since it has been shown (36) that the purine portion of the nucleotide sugar probably contributes to the binding of the substrate to the glycosyltransferase, the inhibition observed here with UMP and UTP was not unexpected. Although this inhibition may play a role in the regulation of the galactosyltransferase activity, no further evidence is available at present.

$N$-acetylglucosamine and a modified fetuin acceptor with terminal $\mathrm{N}$-acetylglucosamine residues were the best acceptors for the galactosyltransferase. In the presence of $\alpha$-lactalbumin, however, $N$-acetylglucosamine became a poor acceptor and glucose, which is normally not an acceptor for the enzyme, became an excellent acceptor for galactose to form lactose. Addition of $\alpha$ lactalbumin did not markedly change the ability of the enzyme to transfer galactose to the glycoprotein acceptor. The effects of $\alpha$-lactalbumin on the serum and erythrocyte membrane galactosyltransferases are similar to those it produces on the lactose synthetase system $(22,37)$.
TABLE IV

Galactosyltransferase Activnty in Human Serum and Erythrocyte Membrane

\begin{tabular}{|c|c|c|c|c|c|c|}
\hline \multirow[b]{3}{*}{ Donor } & \multirow[b]{3}{*}{ Sex } & \multirow{2}{*}{\multicolumn{2}{|c|}{ Blood type }} & \multirow{3}{*}{$\begin{array}{c}\text { Secretor } \\
\text { status }\end{array}$} & \multicolumn{2}{|c|}{ Enzyme activity } \\
\hline & & & & & \multirow[b]{2}{*}{ Serum } & \multirow{2}{*}{$\begin{array}{l}\text { Erythrocyte } \\
\text { membrane }\end{array}$} \\
\hline & & $\mathrm{ABO}$ & $\mathbf{M N}$ & & & \\
\hline & & & & & \multicolumn{2}{|c|}{$d p m / m g$ protein $/ h r$} \\
\hline DM & $\mathbf{M}$ & $\mathbf{A}$ & $\mathbf{M}$ & $\mathbf{S}$ & 9,769 & 2,805 \\
\hline JP & $\mathbf{M}$ & $\mathbf{A}$ & $\mathbf{M}$ & $\mathbf{S}$ & 10,504 & 2,854 \\
\hline EY & $\mathbf{M}$ & $\mathbf{A}$ & MN & $\mathbf{S}$ & 7,691 & 1,650 \\
\hline TS & $\mathbf{F}$ & $\mathbf{A}$ & $*$ & $\mathbf{N}$ & 8,051 & 1,735 \\
\hline $\mathbf{R I}$ & $\mathbf{M}$ & $\mathbf{A}$ & $\mathbf{N}$ & $\mathbf{S}$ & 6,406 & 1,420 \\
\hline $\mathbf{R C}$ & $\mathbf{F}$ & $\mathbf{A}$ & $*$ & $\mathbf{N}$ & 9,265 & 2,105 \\
\hline JW & $\mathbf{M}$ & B & $\mathbf{M}$ & $\mathbf{N}$ & 10,530 & 2,690 \\
\hline $\mathbf{Z P}$ & $\mathbf{F}$ & B & $\mathbf{M}$ & $\mathbf{S}$ & 7,608 & 1,885 \\
\hline JV & $\mathbf{M}$ & $\mathbf{B}$ & $\mathbf{N}$ & $\mathbf{N}$ & 6,869 & 1,650 \\
\hline AS & $\mathbf{M}$ & $\mathbf{B}$ & $\mathbf{M N}$ & $\mathbf{S}$ & 9,784 & 2,465 \\
\hline NH & $\mathbf{M}$ & B & $\mathbf{M}$ & $\mathbf{N}$ & 7,193 & 1,680 \\
\hline WF & $\mathbf{M}$ & B & $\mathbf{M}$ & $\mathbf{S}$ & 8,948 & 2,130 \\
\hline HD & $\mathbf{M}$ & B & $*$ & $\mathbf{S}$ & 10,611 & 3,480 \\
\hline MN & $\mathbf{F}$ & $\mathrm{AB}$ & $*$ & $\mathbf{S}$ & 8,732 & 2,520 \\
\hline $\mathbf{Y K}$ & $\mathbf{M}$ & $\mathbf{A B}$ & $*$ & $\mathbf{N}$ & 7,799 & 2,275 \\
\hline EB & $\mathbf{F}$ & AB & * & $\mathbf{N}$ & 7,104 & 1,675 \\
\hline JN & F & 0 & $\mathbf{N}$ & $\mathbf{S}$ & 9,187 & 2,225 \\
\hline WK & $\mathbf{M}$ & o & MN & $\mathbf{S}$ & 7,794 & 2,085 \\
\hline AB & $\mathbf{M}$ & $\mathbf{O}$ & $\mathbf{M}$ & $\mathbf{N}$ & 6,761 & 1,855 \\
\hline
\end{tabular}

The incubations were performed as described in Methods. Secretor status: S, secretor; N, nonsecretor. Sex: M, male; F, female. Subjects' ages varied from 22 to 50 .

* Not determined.

Brodbeck and Ebner (37) resolved lactose synthetase into two protein fractions, designated $\mathrm{A}$ and $\mathrm{B}$, both of which were required for the synthesis of lactose. It has been shown by Brew, Vanaman, and Hill (34) that the A protein alone catalyzes the transfer of galactose from UDP-galactose to $N$-acetylglucosamine. The B protein, $\alpha$-lactalbumin, when added to the galactosyltransferase (A protein), lowered the $K_{m}$ for glucose and allowed the formation of lactose (22). In the absence of $\alpha$-lactalbumin, glucose was a poor acceptor for the A protein. The galactosyltransferase from human serum and erythrocyte membranes has properties similar to the A protein of lactose synthetase, that is, addition of $\alpha$-lactalbumin alters the catalytic properties of the enzyme enabling it to form lactose with glucose as the acceptor. In the absence of $\alpha$-lactalbumin the galactosyltransferase studied here showed no ability to utilize glucose as an acceptor, suggesting $\alpha$-lactalbumin is not present to any appreciable degree in human serum. Using the serum as the enzyme source, OSM with terminal $N$-acetylgalactosamine and free $N$-acetylgalactosamine were also acceptors for galactose. The trans-

(a) UDP-Gal + GlcNAc-glycoprotein $\longrightarrow$ Gal-GlcNAc-glycoprotein + (UDP)

(b) UDP-Gal + GlcNAc $\longrightarrow$ Gal-GlcNAc + (UDP) $+\alpha$-Lactalbumin

(c) UDP-Gal + Glc $\longrightarrow$ Gal-Glc + (UDP)

FIGURE 9 Summary of galactosyltransferase reactions. 
fer of galactose to $N$-acetylglucosamine was markedly reduced by the presence of $\alpha$-lactalbumin but the addition to $N$-acetylgalactosamine was only marginally affected, indicating there may be two different enzymes involved. Schachter, McGuire, and Roseman (20) have recently reported that there appears to be at least two galactosyltransferases present in porcine submaxillary gland, one adding galactose to $N$-acetylglucosamine, another to a $N$-acetylgalactosamine-terminating acceptor.

Clearly the most immediate questions which arise concern the origin and biological functions of these enzymes. The serum glycosyltransferases may well be of diverse origin and may arise not only from blood cells but also from other sources, e.g., liver, brain, mammary gland, etc. Equally, the demonstration of these enzymes in the red cell membrane does not prove that they originate or play a vital role in that tissue, that is, their presence may be a result of adsorption from serum. However, the effect of detergents suggests that they are bound to structural components. Furthermore, since glycoproteins may be involved in various cell surface phenomena it is tempting to postulate a role for the soluble glycosyltransferases in the synthesis or maintenance of surface components, be they concerned with blood group determination, transport processes, cellular adhesion, tumor antigenicity, or perhaps with the clearance of specific components from the circulation. In light of recent findings $(38-40)$ that desialization of glycoproteins with consequent exposure of galactose as a terminal sugar leads to their rapid removal by the liver from the circulation, the need to preserve intact the carbohydrate moiety of serum glycoprotein is evident. Purification of the serum glycosyltransferases, together with data on the turnover rates of the enzymes in various organs and in different phases of organ function or disease are clearly needed. The fact that the serum, erythrocyte membrane and other $(19,23)$ galactosyltransferases share with the A protein of lactose synthetase a susceptibility to modification by $\alpha$-lactalbumin is also of considerable interest. It is reasonable to suppose that other glycosyltransferases may interact with modifiers, altering the substrate or acceptor specificities of these enzymes, thus providing a general mechanism in the regulation of glycoprotein biosynthesis.

\section{ACKNOWLEDGMENTS}

Ovine submaxillary mucin was kindly supplied by Dr. Ward Pigman. We gratefully acknowledge the excellent technical assistance of Miss Judith Nordberg and Mr. Yong Whan Kim, the secretarial aid of Mrs. Fay Avrech and the help of our librarian, Miss Eloise J. Ryan. We are indebted to Dr. Denis McCarthy for critically reviewing the manuscript.

This work was supported in part by Veterans Administration Research Grant and V. A. RE TR-48.

\section{REFERENCES}

1. Wallach, D. F. H., and V. B. Kamat. 1966. The contribution of sialic acid to the surface charge of fragments of plasma membrane and endoplasmic reticulum. J. Cell. Biol. 30: 660 .

2. Rambourg, A., M. Neutra, and C. P. Leblond. 1966. Presence of a "cell coat" rich in carbohydrate at the surface of cells in the rat. Anat. Rec. 154: 41.

3. Rosenberg, S. A., and G. Guidotti. 1968. The protein of human erythrocyte membranes. 1. Preparation, solubilization and partial characterization. J. Biol. Chem. 243: 1985.

4. Blumenfeld, O. 1968. The proteins of the erythrocyte membrane obtained by solubilization with aqueous pyridine solution. Biochem. Biophys. Res. Commun. 30: 200.

5. Winzler, R. J., E. D. Harris, D. J. Pekas, C. A. Johnson, and P. Weber. 1967. Studies on glycopeptides released by trypsin from intact human erythrocytes. Biochemistry. 6: 2195.

6. Winzler, R. J. 1969. A glycoprotein in human erythrocyte membranes. In Red Cell Membrane, Structure and Function. G. A. Jamieson and T. J. Greenwalt, editors. J. B. Lippincott Co., Philadelphia, Pa. 157.

7. Koscielak, J., and K. Zakrzewsky. 1960. Substance from erythrocyte of blood group A. Nature (Lond.). 187: 516.

8. Hakomori, S., and R. W. Jeanloz. 1961. Isolation and characterization of glycolipids from erythrocytes of human blood A (plus) and B (plus). J. Biol. Chem. 236: 2827.

9. Kathan, R. N., R. J. Winzler, and C. A. Johnson. 1961. Preparation of an inhibitor of viral hemagglutination from human erythrocytes. J. Exp. Med. 113: 37.

10. Langley, O. K., and E. J. Ambrose. 1964. Isolation of a mucopeptide from the surface of Ehrlich ascites tumor cells. Nature (Lond.). 204: 53.

11. Gold, P., M. Gold, and S. O. Freedman. 1968. Cellular location of carcinoembryonic antigens of the human digestive system. Cancer Res. 28: 1331.

12. Glick, J. L., A. R. Goldberg, and A. B. Pardee. 1966. The role of sialic acid in the release of proteins from L 1210 leukemic cells. Cancer Res. 26: 1774.

13. Richmond, J. E., R. M. Glaeser, and P. Todd. 1968. Protein synthesis and aggregation of embryonic cells. Exp. Cell Res. 52 : 43.

14. Roseman, S. 1970. The synthesis of complex carbohydrates by multiglycosyltransferase systems and their potential function in intracellular adhesion. Chem. Phys. Lipids. 5 : 270.

15. Roseman, S. 1968. Biosynthesis of glycoproteins, gangliosides and related substances. In Biochemistry of Glycoproteins and Related Substances. Proceedings of the Fourth International Conference on Cystic Fibrosis of the Pancreas. S. Karger AG., Basel, Switzerland. 244.

16. Kim, Y. S., J. Perdomo, A. Bella, Jr., and J. Nordberg. 1971. N-Acetylgalactosaminyltransferase in human serum and erythrocyte membranes. Proc. Natl. Acad. Sci. U.S. A. 68: 1753 .

17. Kim, Y. S., J. Perdomo, A. Bella, Jr., and J. Nordberg. 1971. Properties of a CMP-N-acetylneuraminic acid: glycoprotein sialyltransferase in human serum and erythrocyte membranes. Biochim. Biophy's. Acta. 244: 505.

18. Spiro, M. J., and R. G. Spiro. 1968. Glycoprotein biosynthesis: studies on thyroglobulin. Thyroid galactosyltransferase. J. Biol. Chem. 243: 6529. 
19. Schachter, H., I. Jabbal, R. L. Hudgin, R. L., and L. Pinteric. 1970. Intracellular localization of liver sugar nucleotide glycoprotein glycosyltransferase in a Golgirich fraction. J. Biol. Chem. 245: 1090.

20. Schachter, H., E. J. McGuire, and S. Roseman. 1971. Sialic acids. XIII. A uridine diphosphate D-galactose: mucin galactosyltransferase from porcine submaxillary gland. J. Biol. Chem. 246: 5321.

21. Kim, Y. S., J. Perdomo, and J. Nordberg. 1971. Glycoprotein biosynthesis in small intestinal mucosa. I. A study of glycosyltransferases in microsomal subfractions. J. Biol. Chem. 246: 5466.

22. Schanbacher, F. L., and K. E. Ebner. 1970. Galactosy1transferase acceptor specificity of the lactose synthetase A protein. J. Biol. Chem. 245: 5057.

23. Den, H., B. Kaufman, and S. Roseman. 1970. Properties of some glycosyltransferases in embryonic chicken brain. J. Biol. Chem. 245 : 6607.

24. Hudgin, R. L., and H. Schachter. 1971. Porcine sugar nucleotide: glycoprotein glycosyltransferase. II. Blood serum and liver galactosyltransferase. Can. J. Biochem. $49: 829$.

25. Wagner, R. R., and M. A. Cynkin. 1971. Glycoprotein metabolism: A UDP-galactose: glycoprotein galactosyltransferase of rat serum. Biochem. Biophys. Res. Commun. 45 : 57.

26. Dodge, J., C. Mitchell, and D. Hanahan. 1963. The preparation and chemical characteristics of hemoglobinfree ghosts of human erythrocytes. Arch. Biochem. Biophys. 100: 119.

27. Spiro, R. G. 1964. Periodate oxidation of the glycoprotein fetuin. J. Biol. Chem. 239: 567.

28. McGuire, E. J. 1970. Biosynthesis of submaxillary mucins. In Blood and Tissue Antigens. D. Aminoff, editor. Academic Press, Inc., New York. 461.

29. Spiro, R. G. 1960. Studies on fetuin, a glycoprotein of fetal serum. I. Isolation, chemical composition and physicochemical properties. J. Biol. Chem. 235: 2860.
30. Payza, N., S. Rizvi, and W. Pigman. 1969. Studies of action of acids and bases on porcine submaxillary mucin. Arch. Biochem. Biophys. 129: 68.

31. Lowry, O. H., N. J. Rosebrough, A. L. Farr, and R. J. Randall. 1951. Protein measurement with the Folin phenol reagent. J. Biol. Chem. 193: 265.

32. Spiro, R. G. 1970. Glycoproteins. Annu. Rev. Biochem. 599.

33. Ziderman, D., S. Gompertz, Z. G. Smith, and W. M. Watkins. 1967. Glycosyltransferases in mammalian gastric mucosal linings. Biochem. Biophys. Res. Comm. 29: 56.

34. Brew, K., R. C. Vanaman, and R. L. Hill. 1968. The role of $\alpha$-lactalbumin and the $A$ protein in lactose synthetase: a unique mechanism for the control of a biological reaction. Proc. Natl. Acad. Sci. U. S. A. 59: 491.

35. Babad, H., and Hassid, W. Z. 1966. Soluble uridine diphosphate D-galactose: D-glucose $\beta$-4-D-galactosyltransferase from bovine milk. J. Biol. Chem. 241: 2672.

36. Bella, A., Jr., Y. S. Kim. 1971. Inhibition of rat intestinal $\alpha(1 \rightarrow 2)$ fucosyltransferase. Biochem. J. 125: 1157.

37. Brodbeck, U., and K. E. Ebner. 1966. Resolution of a soluble lactose synthetase into two components and solubilization of microsomal lactose synthetase. J. Biol. Chem. 241 : 762.

38. Morell, A. G., G. Gregoriadis, I. H. Scheinberg, J. Hickman, and G. Ashwell. 1971. The role of sialic acid in determining the survival of glycoproteins in the circulation. J. Biol. Chem. 246: 1461.

39. Rogers, J. C., and S. Kornfeld. 1971. Hepatic uptake of proteins coupled to fetuin glycopeptides. Biochem. Biophys. Res. Commun. 45: 622.

40. Nelsestuen, G. L., and J. W. Suttie. 1971. Properties of asialo and aglycoprothrombin. Biochem. Biophys. Res. Commun. 45: 198. 